\title{
Cytotaxonomy of some species and of interspecific hybrids of Pennisetum (Poaceae, Poales)
}

\author{
Vânia Helena Techio ${ }^{1}$, Lisete Chamma Davide ${ }^{2}$, Antônio Vander Pereira ${ }^{3}$ and Eduardo Bearzoti ${ }^{4}$ \\ ${ }^{1}$ Universidade do Contestado, UnC-Concórdia, Santa Catarina, Brazil. \\ ${ }^{2}$ Departamento de Biologia, Universidade Federal de Lavras-UFLA, Lavras, MG, Brazil. \\ ${ }^{3}$ Embrapa Gado de Leite. Juiz de Fora, Minas Gerais, Brazil. \\ ${ }^{4}$ Departamento de Ciências Exatas, Universidade Federal de Lavras-UFLA, Lavras, MG, Brazil.
}

\begin{abstract}
Cytotaxonomic studies were carried out on 26 accessions of Pennisetum spp. originating from the Active Germplasm Bank of Embrapa Gado de Leite-Juiz de Fora, Minas Gerais, Brazil.This study presents cytogenetics and reproductive morphological data for each one of these accessions, which allowed groupings and suggest botanical identifications to be established. The metaphases of the accessions characterized as $P$. purpureum confirmed the presence of $2 \mathrm{n}=28$ chromosomes that have already been described for this species. For the hybrids between $P$. purpureum and $P$. glaucum and for the hexaploids, resulting from the chromosome duplication of these hybrids, $2 \mathrm{n}=$ 21 and $2 n=42$ chromosomes were confirmed, respectively. The wild accession identified as $P$. setosum showed metaphases with $2 n=54$ chromosomes, while those characterized as $P$. nervosum had cells with $2 n=36$ chromosomes. The wild accession 15 was different from the others for the morphological characters, with $2 n=36$ chromosomes, and was classified as $P$. orientale. Two statistical procedures were used (canonical variables and cluster analysis on the basis of the Mahalanobis distance), and the results confirmed the conclusions obtained from the cytogenetic and morphologic analysis.
\end{abstract}

Key words: Pennisetum, cytogenetic, taxonomy, germplasm, genetic divergence.

Received: March 5, 2002; accpeted: June 24, 2002.

\section{Introduction}

The genus Pennisetum Rich. contains about 140 species, comprising such important cultivated species as napiergrass, pearl millet and kikuyu grass (Brunken, 1977; Kativu and Mithen, 1987). The species belonging to this genus constitute a heterogeneous assemblage with different basic chromosome numbers ( $x=5,7,8$ and 9), ploidy levels varying from diploid to octoploid, sexual or apomictic reproductive behavior and annual, biennial or perennial life cycle (Martel et al., 1997).

Napiergrass (Pennisetum purpureum Schumach.), due to its high productive potential, carrying capacity and nutritient quality, has been highlighted as one of the most important tropical forages for dairy grazing system improvement in the tropics. (Pereira, 1994). Pearl millet [Pennisetum glaucum (L.) R. Br.] is a species with a dual purpose; grains are used for human consumption and for cattle forage (Minocha, 1991).

Send correspondence to L.C.D. Departamento de Biologia, Universidade Federal de Lavras - UFLA, Caixa Postal 37, 37.200-000 Lavras, Minas Gerais, Brasil. E-mail: Icdavide@ufla.br.
Napiergrass and pearl millet germplasm offers great diversity in types of plants as well as wide genetic variability for the great majority of the characters of forage importance. Also, among the wild species of Pennisetum, there is great variation for these characteristics, with some of them having potential for napier grass breeding. However, the use of these species depends on the genetic compatibility with napiergrass.

Because of the great diversity of types and forms of Pennisetum and the possibility of substitution of the cultivar's common names in the introduction processes, the characterization and taxonomic classification has become confusing, imprecise and even controversial at times. Some studies have used eletrophoretic separation through isozyme patterns, cytogenetics analysis and flow cytometry to characterize cultivars of numerous species, including those belonging to the Pennisetum genus (Manara, 1973; Hanna, 1981; Dujardin and Hanna, 1983 and 1985; Hanna and Dujardin, 1986; Daher, 1993; Passos and Vidigal, 1994; Passos et al., 1994). However, little or no relationship has been shown between the results of these studies and taxonomy. 
The objective of this study was to characterize cytogenetically and morphologically some accessions of Pennisetum belonging to the Active Germplasm Bank at Embrapa Gado de Leite.

\section{Material and Methods}

Twenty-six Pennisetum spp. accessions belonging to the Active Germplasm Bank at Embrapa Gado de Leite, Juiz de Fora, Minas Gerais, Brazil were evaluated including six $P$. purpureum accessions, five $P$. purpureum and $P$. glaucum interspecific hybrids and fifteen Pennisetum spp. accessions. The Pennisetum spp. accessions were collected in several different areas of Brazil and have not yet received any identification type or post-collection characterization. The accessions were identified as BAG (Active Germplasm Bank). The root tip cells were used for cytogenetic analysis. The material was submitted to cell cycle synchronization (Lee et al., 1997) using $2.5 \mathrm{mM}$ hydroxyurea solution for $14 \mathrm{~h}$. The roots were pretreated with $25 \mathrm{mg} / \mathrm{L}$ cycloheximide and $300 \mathrm{mg} / \mathrm{L}$ hydroxyquinoline (1:1) solution for $2 \mathrm{~h} 45^{\prime}$, fixed in Carnoy solution for $24 \mathrm{~h}$, and submitted to enzymatic maceration in pectinase. They were stained with Schiff reagent and the slides prepared by the smear technique. Twenty-one of the 26 accessions were morphologically evaluated considering the following characteristics: panicle length and width, spikelet number and size, number of bristles, length of the longest bristle, length and number of ribs of the 1st, 2 nd and 3rd glume, length and number of ribs of the palea, length of the lemma and length of the anthers. The accessions BAG 27, BAG 54, F92-167-2 and wild accessions 5 and 7 were not evaluated morphologically because they had no inflorescences during the collection and analysis periods. For the other materials, voucher specimens were prepared and kept in the herbarium of the Department of Biology (Universidade Federal de LavrasUFLA, Lavras, Minas Gerais, Brazil). The experimental units, in which the evaluations were made, corresponded to the inflorescences of a same plant, the representative of the accession in the Germplasm Bank. Thus, a completely randomized design with 3 replications was considered, allowing the decomposition of the sums of squares and of products between and within accessions. Two statistical procedures were used (canonical variables and cluster analysis on the basis of Mahalanobis distance) to study the genetic divergence among the accessions and to establish relationships among the results obtained from the application of these two methods and those derived from the association between the cytogenetic and morphologic characters.

\section{Results and Discussion}

Groupings could be established among the accessions from the results of the cytogenetic and morphological analysis based on the degree of similarity. Each group was

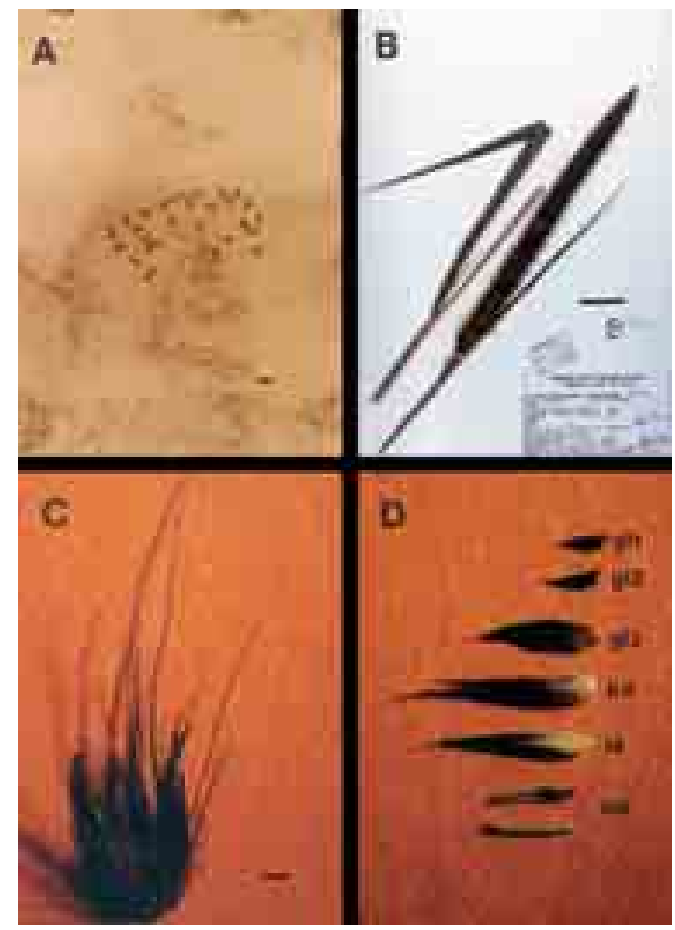

Figure 1 - BAG 65 (P. purpureum). A. Mitotic metaphase with $2 \mathrm{n}=28$ chromosomes; B. Specimens; C. Spikelet; D. Constituent of the spikelet: an (anthers), le (lemma), pa (palea), gl3 ( $3^{\text {rd }}$ glume), gl2 ( $2^{\text {nd }}$ glume $)$, gl1 ( $1^{\text {st }}$ glume). The bars represent: A. $5 \mu \mathrm{m}$; B. $5.6 \mathrm{~cm}$; C and D. $2.3 \mathrm{~mm}$. UFLA. Lavras, MG, Brazil, 1998.

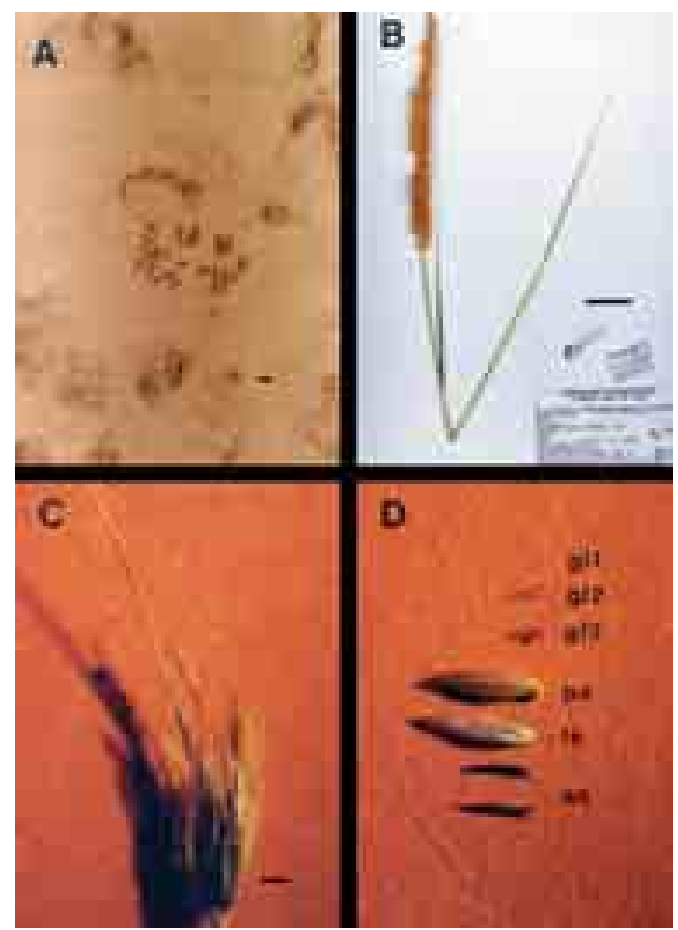

Figure 2 - BAG F92-176-1 (Interspecific hybrids between $P$. purpureum and P. glaucum). A. Mitotic metaphase with $2 \mathrm{n}=21$ chromosomes; B. Specimens; C. Spikelet; D. Constituent of the spikelet: an (anthers), le (lemma), pa (palea), gl3 ( $3^{\text {rd }}$ glume $)$, gl2 ( $2^{\text {nd }}$ glume $)$, gl1 ( $1^{\text {st }}$ glume $)$. The bars represent: A. $5 \mu \mathrm{m}$; B. $5.6 \mathrm{~cm}$; C and D. $2.3 \mathrm{~mm}$. UFLA. Lavras, MG, Brazil, 1998. 


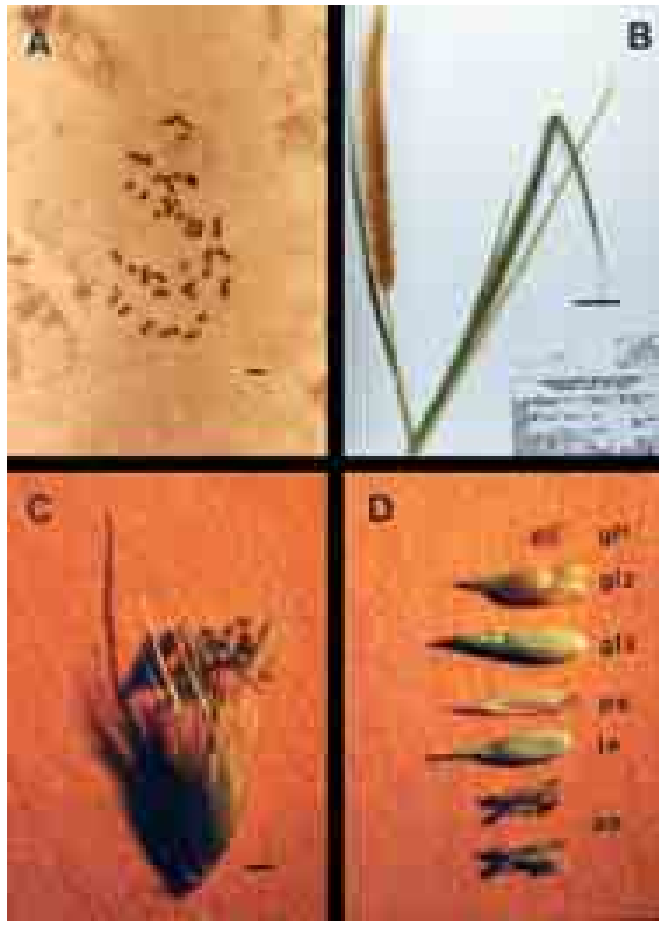

Figure 3 - BAG Hexaploid 204. A. Mitotic metaphase with 2n $=42$ chromosomes; B. Specimens; C. Spikelet; D. Constituent of the spikelet: an (anthers), le (lemma), pa (palea), gl3 ( $3^{\text {rd }}$ glume $)$, gl2 ( $2^{\text {nd }}$ glume), gl1 ( $1^{\text {st }}$ glume). The bars represent: A. $5 \mu \mathrm{m}$; B. $5.6 \mathrm{~cm}$; C and D. $2.3 \mathrm{~mm}$. UFLA. Lavras, MG, Brazil, 1998.

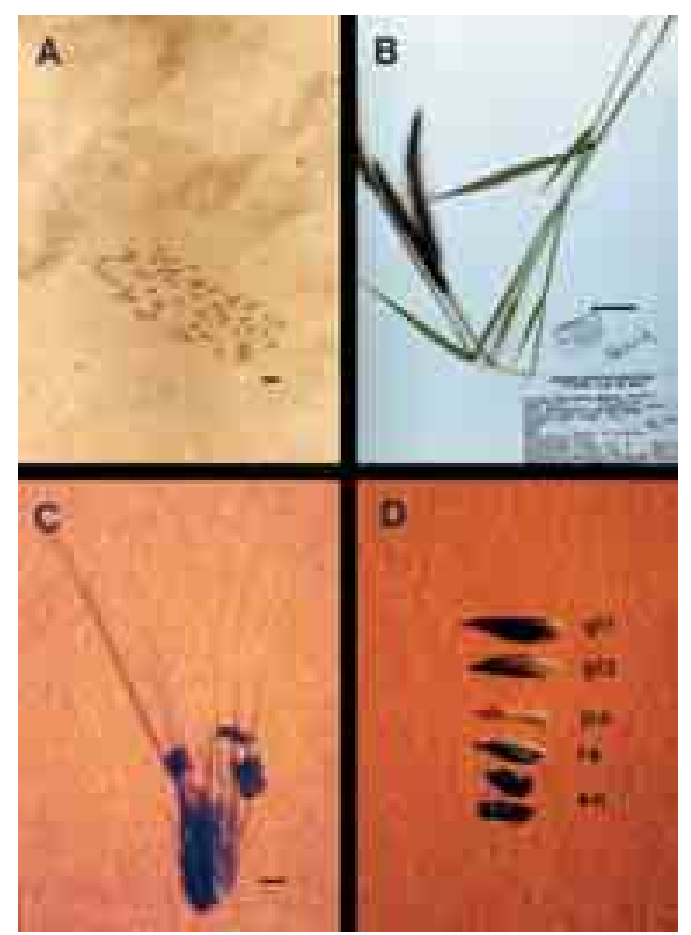

Figure 4 - Wild BAG 3 (P. setosum). A. Mitotic metaphase with $2 \mathrm{n}=54$ chromosomes; B. Specimens; C. Spikelet; D. Constituent of the spikelet: an (anthers), le (lemma), pa (palea), gl2 ( $2^{\text {nd }}$ glume $)$, gl1 ( $1^{\text {st }}$ glume $)$. The bars represent: A. $5 \mu \mathrm{m}$; B. $5.6 \mathrm{~cm}$; C and D. $2.3 \mathrm{~mm}$. UFLA. Lavras, $\mathrm{MG}$, Brazil, 1998.

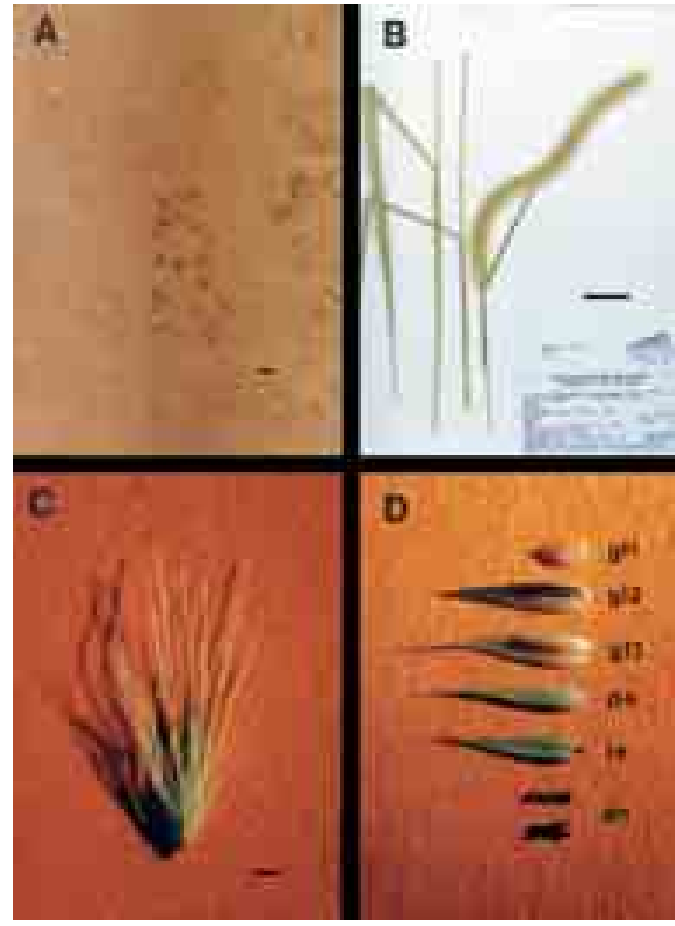

Figure 5 - Wild BAG 12 (P. nervosum). A. Mitotic metaphase with 2n= 36 chromosomes; B. Specimens; C. Spikelet; D. Constituent of the spikelet: an (anthers), le (lemma), pa (palea), g13 ( $3^{\text {rd }}$ glume), g12 ( $2^{\text {nd }}$ glume), gl1 ( $1^{\text {st }}$ glume). The arrows indicate satellites and the bars represent: A. $5 \mu \mathrm{m}$; B. $5.6 \mathrm{~cm}$; C and D. $2.3 \mathrm{~mm}$. UFLA. Lavras, MG, Brazil, 1998.

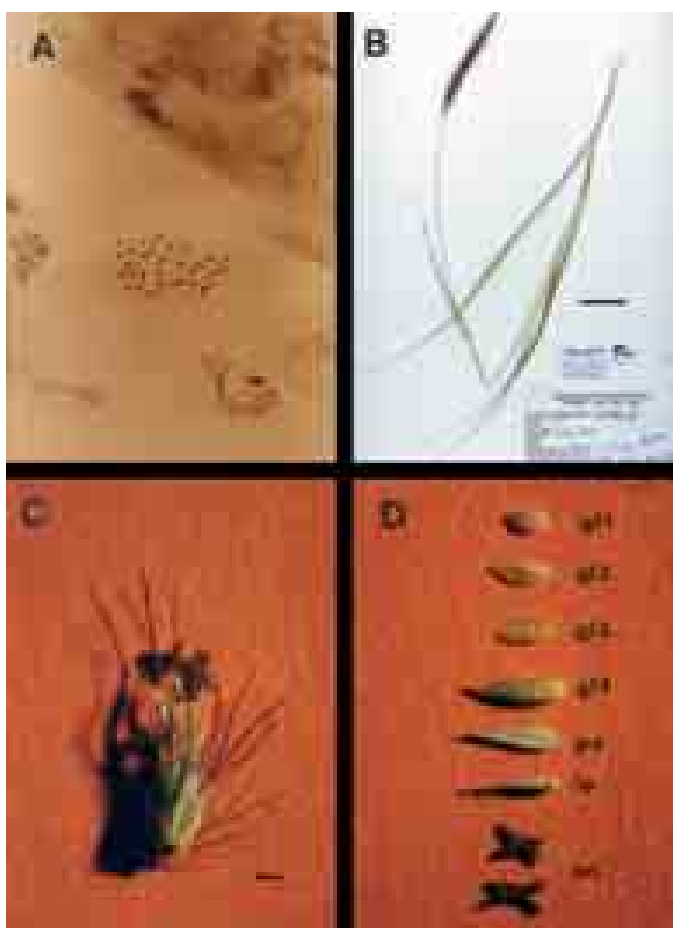

Figure 6 - Wild BAG 15 (P. af. orientale). A. Mitotic metaphase with $2 \mathrm{n}=36$ chromosomes; B. Specimens; C. Spikelet; D. Constituent of the spikelet: an (anthers), le (lemma), pa (palea), gl4 ( $4^{\text {th }}$ glume), gl3 ( $3^{\text {rd }}$ glume), gl2 ( $2^{\text {nd }}$ glume $)$, gl1 ( $1^{\text {st }}$ glume $)$ The bars represent: A. $5 \mu \mathrm{m} ;$ B. 5.6 $\mathrm{cm}$; C and D. 2.3 mm. UFLA. Lavras, MG, Brazil, 1998. 
Table I - Chromosome number and identification of the accessions of Pennisetum spp. of the Active Germplasm Bank of Embrapa Gado de Leite. UFLA. Lavras, Minas Gerais, Brazil, 1998.

\begin{tabular}{|c|c|c|c|}
\hline Accessions & Chromosome number & Former identification & Actual identification \\
\hline BAG 27 & 28 & P. purpureum & P. purpureum \\
\hline BAG 45 & 28 & Interspecific hybrid & P. purpureum \\
\hline BAG 46 & 28 & Interspecific hybrid & P. purpureum \\
\hline BAG 54 & 28 & P. purpureum & P. purpureum \\
\hline BAG 65 & 28 & P. purpureum & P. purpureum \\
\hline BAG 103 & 28 & P. purpureum & P. purpureum \\
\hline F92-167-2 & 21 & Interspecific hybrid & Interspecific hybrid \\
\hline F92-167-1 & 21 & Interspecific hybrid & Interspecific hybrid \\
\hline F92-176-1 & 21 & Interspecific hybrid & Interspecific hybrid \\
\hline Hexaploid 199 & 42 & Interspecific hybrid & Interspecific hybrid \\
\hline Hexaploid 204 & 42 & Interspecific hybrid & Interspecific hybrid \\
\hline Wild BAG 3 & 54 & P. pedicellatum & P. setosum \\
\hline Wild BAG 4 & 54 & P. polystachyon & P. setosum \\
\hline Wild BAG 5 & 54 & P. polystachyon & P. setosum \\
\hline Wild BAG 6 & 54 & P. polystachyon & P. setosum \\
\hline Wild BAG 1 & 36 & P. nervosum & P. nervosum \\
\hline Wild BAG 7 & 36 & P. nervosum & P. nervosum \\
\hline Wild BAG 8 & 36 & P. nervosum & P. nervosum \\
\hline Wild BAG 9 & 36 & P. pedicellatum & P. nervosum \\
\hline Wild BAG 10 & 36 & P. polystachyon & P. nervosum \\
\hline Wild BAG 12 & 36 & not identified & P. nervosum \\
\hline Wild BAG 13 & 36 & P. nervosum & P. nervosum \\
\hline Wild BAG 14 & 36 & P. latifolium & P. nervosum \\
\hline Wild BAG 16 & 36 & P. nervosum & P. nervosum \\
\hline Wild BAG 17 & 36 & P. nervosum & P. nervosum \\
\hline Wild BAG 15 & 36 & P. nervosum & $P$. af. orientale \\
\hline
\end{tabular}

represented by a photograph of an accession (Figures 1 to 6). Botanical identifications could also be suggested and compared to those already existing in the Active Germplasm Bank (Table I).

\section{Group 01: BAGs 27, 45, 46, 54, 65 and 103}

The cytogenetic analysis performed for these materials revealed a chromosome number of $2 \mathrm{n}=28$ (Figure 1) that is in line with the literature, that corresponded to the chromosome number of $P$. purpureum, which was determined for the first time by Burton (1942) and confirmed by Manara (1973), Brunken (1977), Jauhar (1981) and Dujardin and Hanna (1985).

The presence of satellites was observed in two chromosomes in the metaphases of BAG 27 and BAG 54. Manara (1973) had previously recorded the presence of these structures in P. purpureum, although in only one of the homologs of the chromosome pair, with variation in number from 1 to 2 .
Morphologically, accessions 45, 46, 65 and 103 all agreed with the botanical description of $P$. purpureum (Hitchcock, 1935; Bogdan, 1977; Brunken, 1977 and Kativu and Mithen, 1987), especially in relation to panicle and spikelet color and length and number, length and color of the bristles.

\section{Group 02: BAGs F92-176-1, F92-167-1 and F92-167-2}

The number $2 \mathrm{n}=21$ chromosomes (Figure 2) confirmed the hybrid origin of these accessions, resulting from different crossings between P. purpureum and P. glaucum. In the analyzed metaphases it was possible to ascertain the presence of 7 larger chromosomes originating from $P$. glaucum and the other from $P$. purpureum. This observation agrees with the results obtained by Burton (1942), who studied the cytological behavior of the hybrids between these two species. 
There is little bibliographical information available concerning measurements of the structures that compose the inflorescence for hybrids between $P$. purpureum and $P$. glaucum. Bogdan (1977) reported the superiority of some hybrids over napiergrass after comparing characters such as leaf dimension and number, developed culms, softer leaf hairs and less fibrous stems, and yield.

The simultaneous examination of the characteristics mentioned above for accessions 45, 46, 65 and 103, defined as $P$. purpureum, and for hybrids F92-167-1 and F92176-1, although restricted to inflorescence data, showed similarity among them. Although no analogy has been observed for P. glaucum, it was possible to observe many structures characteristic of $P$. purpureum, such as panicle and spikelet shape, size and color appearing in the hybrids. This information agrees with the report of Gonzales and Hanna (1984) justifying the greatest genetic contribution and dominance of the $\mathrm{B}$ genome of $P$. purpureum over the A genome of $P$. glaucum.

\section{Group 03: BAGs hexaploids 199 and 204}

Group 03 accessions constituted chromosome races originating from the University of Florida and obtained by the chromosome duplication of hybrids between $P$. purpureum and P. glaucum (Pereira, 1994). Metaphases with $2 \mathrm{n}=42$ chromosomes were confirmed for these materials (Figure 3).

As was the case with hybrids, botanical data were not found in the literature for measurements of the reproductive structures for the hexaploids. The morphologic characteristics did not differ significantly from those of the $P$. purpureum varieties.

\section{Group 04: Wild accessions 3, 4, 5 and 6}

The chromosome number $(2 \mathrm{n}=54)$ enabled these four wild accessions to be grouped (Figure 4). The inflorescence morphological characteristics of these accessions were also equivalent (Figure 4).

The phenotypic data were matched to those reported for the $P$. setosum species. (Swartz.) L. Rich. (synonymy $P$. polystachyon Schult.) for Hrishi (1952), Burger (1980), Kativu and Mithen (1987). This was consistent with the key to identification proposed by Hafliger and Scholz (1980), with special reference to the length, width and color of the panicle, spikelet density per $\mathrm{cm}$, presence of solitary spikelets in the involucre, number and size of the bristles and structures of the rachis.

Results described by Hrishi (1952) and Rangasamy (1972) indicating $2 \mathrm{n}=6 \mathrm{x}=54$ chromosomes for $P$. setosum, confirm the classification of the accessions on the basis of the chromosome number information. Other au- thors mentioned by Schmelzer (1997) also report $2 \mathrm{n}=18$, $36,45,48,52$ and 63 chromosomes for this species.

\section{Group 05: Wild accessions 1, 7, 8, 9, 10, 12, 13, 14,} 16 and 17

An important phenotypic characteristic that justified the grouping of these accessions was the absence of longer bristles in the involucre that is typical of the other materials evaluated. The other structures and characteristics of the panicle and spikelet also resembled each other, except the color. In accessions 10, 12 and 14 they were green and in the others they were mainly purple (Figure 5). This information agrees partially with data proposed by Hitchcock (1935), Gould (1975) and Renvoize (1984) for P. nervosum (Ness.) Trin. According to Hitchcock (1935), P. nervosum was already found in Brazil, Ecuador and Argentina.

The chromosome number reported by Gould (1975) for $P$. nervosum is $2 \mathrm{n}=36$, also agreeing with the results obtained in this study for the accessions above. The analysis of the metaphases of these accessions indicated the presence of satellites in 2 chromosomes. The fact that satellites were not observed in all the accessions can be attributed either to the stage of chromosome condensation in the metaphases or to the proximity and overlap of the metaphases, or possibly to the detachment and loss of the satellite. This problem was encountered by Guerra et al. (1997) when analyzing metaphases in Citrus accessions. According to these authors, the observation of both primary and secondary constrictions was impaired by the largest chromossome condensation caused by the pretreatment.

\section{Group 06: Wild accession 15}

Different from the other accessions, especially for the morphological characters, wild accession 15 was considered morphologically similar to the species $P$. orientale Rich. Its botanical description matched the data of Hrishi (1952) for this species, mainly in relation to the length of the panicle, spikelet density per $\mathrm{cm}$, spikelet number in the involucre and glume number (Figure 6). There is also agreement with the chromosome number observed $(2 \mathrm{n}=$ 36 ) and the number reported by this author for the species. However, citations exist describing $2 \mathrm{n}=18,27,45$ and 54 chromosomes (Dujardin and Hanna, 1983).

For the species $P$. orientale, which originated in Africa, neither records of natural occurrence nor of its introduction exist in Brazil. In the Germplasm Bank this accession was introduced as $P$. nervosum, making up a group containing accessions 1, 7, 8, 13, 16 and 17 . The botanical description for the species P. nervosum (Gould, 1975; Renvoize, 1984), however, does not resemble the morphological characters recorded in this work. Also there is not similarity among the phenotypic data of the accessions described above with those described for wild access 15, which accounted for its classification as P. nervosum. 


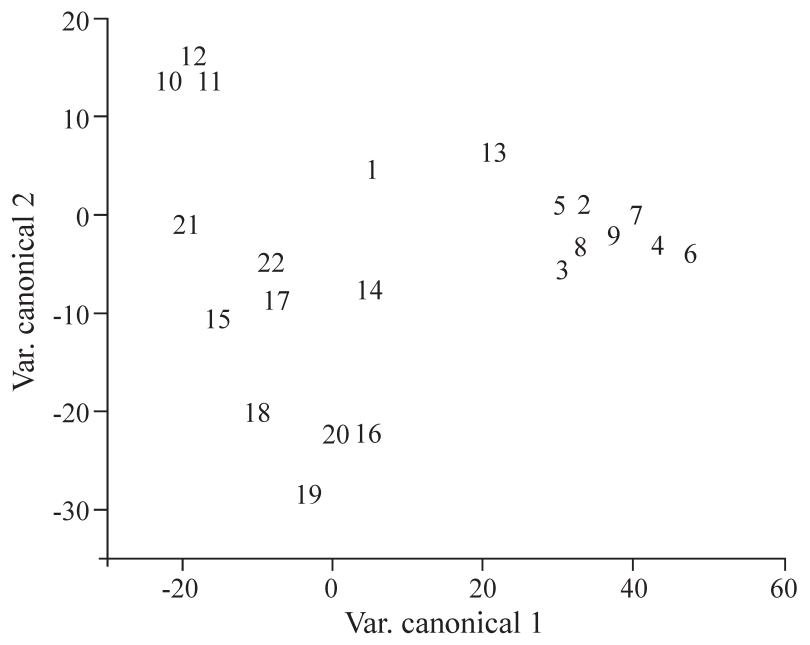

Figure 7 - Graphic dispersion of the scores of the two more important canonical variables for the 21 accessions of Pennisetum spp. of the Active Germplasm Bank of Embrapa Gado de Leite. The numeration corresponds to the accessions: 1 . wild $15 ; 2$. wild $12 ; 3$. wild $10 ; 4$. wild $14 ; 5$. wild $9 ; 6$. wild $16 ; 7$. wild $13 ; 8$. wild $17 ; 9$. wild $1 ; 10$. wild $6 ; 11$. wild $4 ; 12$. wild 3 ; 13. wild 8; 14. BAG 45; 15. Hexaploid 204; 16. Hexaploid 199; 17. F92-167-1; 18. F92-176-1; 19 BAG 65; 20. BAG 46; 21. BAG 103. UFLA. Lavras, MG, Brazil, 1998.

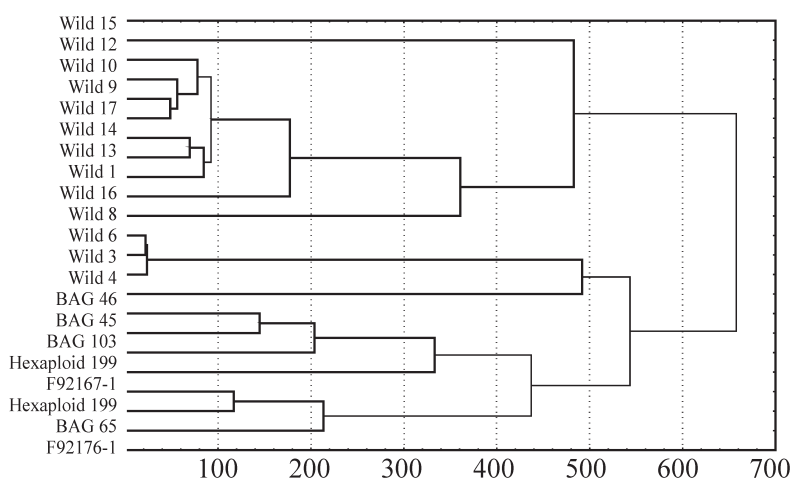

Figure 8 - Dendrogram obtained by the closest neighboring method, from the Mahalanobis distance, for 21 accessions of Pennisetum spp. of the Germplasm Bank of Embrapa Gado de Leite. UFLA. Lavras, MG, Brazil, 1998.

\section{Analysis of genetic divergence}

The results obtained by the application of the two multivariate methodologies through the comparative visualization of the dendrogram corresponding to the cluster analysis and of the graphic dispersion (Figures 7 and 8) showed a good agreement. One exception was F92-167-1, which in the former method was grouped with other accessions, while in the graphic analysis of canonical variables remained as an isolated group. However, it should be noted that its dissimilarity values in relation to the accessions BAG 45, BAG 103 and hexaploid 199, were close to the cut-off value used. It is notable that there is agreement of the analysis when using canonical variables and cluster analysis.
The use of statistical methods corroborated some of the conclusions obtained on the basis of cytogenetic and morphological analysis. Prominence may be given to the groupings among wild accessions 3, 4 and 6 and among wild accessions $1,9,10,12,13,14,16$ and 17 that, except for wild accession 8 , were in accordance for all analysis (cytogenetic and morphologic, canonical variables and of cluster on the basis of Mahalanobis distance).

Some differences were expected in the formation of the groups involving the hybrids, the hexaploids and the accessions of $P$. purpureum. In the latter case, the differences observed can be explained by the existence of a number of varieties of $P$. purpureum carrying some nearly undistinguishable reproductive morphological characteristics. Depending on the approach adopted, those differences may be important parameters. Considering the access BAG 46, characterized as $P$. purpureum, it may be observed that the glumes that compose the spikelet differ, in number, when compared to those of the other accessions of $P$. purpureum: BAG 45, BAG 65 and BAG 103. Because of the greater importance of morphological information with this method (absence of 2 glumes), the cluster analysis and canonical variables considered it to be an isolated item and different from the others.

In the cluster analysis (Figure 8), if the cut-off point for differentiation among the groups is established in about $35 \%$ of the largest distance, the formation of 10 groups is observed. Some accessions, separated in the cluster analysis, resulted in membership of the same group according to the approaches to the cytogenetic and morphologic analysis. For example, in the cluster analysis, accessions BAG 45 and BAG 103 formed a group distinct from the access BAG 46. These three materials, however, were analyzed according to the cytogenetic and morphological analysis. In such cases the contradiction among the approaches are not representative, but reflect the fact that multivariate analysis was more conservative in the formation of groups. The only significant contradiction was the occurrence of hexaploid 204 and access BAG 65 in a same group (Figure 8), which were separated according to the cytogenetic and morphological approaches. Although they resemble each other morphologically, it is more reasonable to maintain them in different groups since they contain different ploidy levels. Especially in the case of the wild materials, the agreement was pointed out among the methodologies, suggesting the viability of its associated use in future studies.

\section{Acknowledgments}

The authors thank to FAPEMIG for the financial support to the research and to CNPq for scoolarship to the first author. 


\section{References}

Bogdan AV (1977) Tropical pasture and fodder plants (grasses and legumes). Longman, London.

Brunken JN (1977) A systematic study of Pennisetum Sect. Pennisetum (Gramineae). American Journal of Botany 64:161-176.

Burger W (1980). Flora costaricensis. Library of Congress, USA.

Burton GW (1942) A cytological study of some species in the Tribe Paniceae. American Journal of Botany 29:355-361.

Daher RR (1993) Diversidade morfológica e isozimática em capim elefante (Pennisetum purpureum Schum.). Master's Thesis, Universidade Federal de Viçosa, Viçosa.

Dujardin M, Hanna WW (1983) Meiotic and reproductive behavior of facultative apomictic $\mathrm{BC}_{1}$ offspring derived from Pennisetum americanum - P. orientale interspecific hybrids. Crop Science 23:156-160.

Dujardin M, Hanna WW (1985) Cytology and reproductive behavior of pearl millet-napiergrass hexaploids x Pennisetum squamulatum trispecific hybrids. The Journal of Heredity 72:382-384.

Gates FC (1936) Grasses in Kansas. Kansas state printing plant, Kansas.

Gonzalez B, Hanna WW (1984) Morphological and fertility responses in isogenic triploid and hexaploid pearl millet $\mathrm{x}$ napier-grass hybrids. The Journal of Heredity 75:317-318.

Gould FW (1975) The grasses of Texas. Texas A \& M University Press, Texas.

Guerra M, Pedrosa A, Barros e Silva AE, Cornelio MTM, Santos K, Soares Filho WSF (1997) Chromosome number and secondary constriction variation in 51 accessions of a citrus germplasm Bank. Revista Brasileira de Genética 20:489-496.

Hafliger E, Scholz H (1980) Grass weeds 1. Ciba-Geigy Ltd., Switzerland.

Hanna WW (1981) Method of reproduction in napiergrass and in the $3 \mathrm{X}$ and $6 \mathrm{X}$ alloploid hybrids with pearl millet. Crop Science 21:123-126.

Hanna WW, Dujardin M (1986) Cytogenetics of Pennisetum schweinfurthii Pilger and its hybrids with pearl millet. Crop Science 26:449-453.
Hitchcock AS (1935) Manual of the grasses of the United States. Government Printing office, Washington.

Hrishi NJ (1952) Studies on the cytogenetics of six species of Pennisetum and their comparative morphology and anatomy. Genetica 26:280-356.

Jauhar PP (1981) Cytogenetics and breeding of pearl millet and related species. Alan R. Liss, New York.

Kativu S, Mithen R (1987) Pennisetum in Southern Africa. Plant Genetic Resources Newsletter 73/74:1-8.

Lee J, Arumuganathan K, Yen Y, Kaeppler S, Kaeppler H, Baenziger PS (1997) Root tip cell-cycle synchronization and metaphase-chromosome isolation suitable for flow sorting in common wheat (Triticum aestivum L.). Genome 40:633-638.

Manara NTF (1973) Citogenética de variedades de capim elefante (Pennisetum purpureum Schum.). Master's thesis, Escola Superior de Agricultura Luiz de Queiroz, Piracicaba.

Martel E, De Nay D, Siljak-Yakovlev S, Brown S, Sarr A (1997) Genome size variation and basic chromosome number in pearl millet and fourteen related Pennisetum species. The Journal of Heredity 88:139-143.

Minocha JL (1991) Pearl millet cytogenetics. In: Gupta PK, Tsuchiya T (eds.) Chromosome engineering in plants genetics. Elsevier, Amsterdam, pp 599-611.

Passos L, Lambert G, Galbraith D (1994) Separação de acessos de capim-elefante com base no teor de DNA genômico, medido por citometria de fluxo. Simpósio sobre capim-elefante. EMBRAPA - CNPGL, Juiz de Fora, p. 212.

Passos L, Vidigal M (1994) Separação de acessos de capimelefante com base em padrões de proteínas obtidos em SDS-PAGE. Simpósio sobre capim-elefante. EMBRAPA CNPGL, Juiz de Fora, p. 211.

Pereira AV (1994) Germoplasma e diversidade genética do capim-elefante. Simpósio sobre capim-elefante. EMBRAPA CNPGL, Juiz de Fora, pp 1-11.

Rangasamy SRS (1972) Cytological studies on diploid and polyploid taxa of the genus Pennisetum Rich. Genetica 43:257-273.

Renvoize SA (1984) The grasses of Bahia. Royal Botanic Gardens, England.

Schmelzer GH (1997) Review of Pennisetum section Brevivalvula (Poaceae). Euphytica 97:1-20. 